\title{
Front Matter: Volume 9027
}

, "Front Matter: Volume 9027," Proc. SPIE 9027, Imaging and Multimedia Analytics in a Web and Mobile World 2014, 902701 (4 March 2014); doi: $10.1117 / 12.2062800$

SPIE Event: IS\&T/SPIE Electronic Imaging, 2014, San Francisco, California, United SPIE. States 


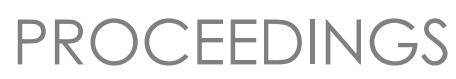

IS\&T / SPIE

Electronic

Imaging

SCIENCE AND TECHNOLOGY

\section{Imaging and Multimedia Analytics in a Web and Mobile World 2014}

Qian Lin

Jan P. Allebach

Zhigang Fan

Editors

5-6 February 2014

San Francisco, California, United States

Sponsored and Published by

IS\&T-The Society for Imaging Science and Technology

SPIE 
The papers included in this volume were part of the technical conference cited on the cover and title page. Papers were selected and subject to review by the editors and conference program committee. Some conference presentations may not be available for publication. The papers published in these proceedings reflect the work and thoughts of the authors and are published herein as submitted. The publishers are not responsible for the validity of the information or for any outcomes resulting from reliance thereon.

Please use the following format to cite material from this book:

Author(s), "Title of Paper," in Imaging and Multimedia Analytics in a Web and Mobile World 2014 edited by Qian Lin, Jan P. Allebach, Zhigang Fan, Proceedings of SPIE-IS\&T Electronic Imaging, SPIE Vol. 9027. Article CID Number (2014)

ISSN: 0277-786X

ISBN: 9780819499448

Copublished by

SPIE

P.O. Box 10, Bellingham, Washington 98227-0010 USA

Telephone +1 3606763290 (Pacific Time) · Fax +1 3606471445

SPIE.org

and

IS\&T-The Society for Imaging Science and Technology

7003 Kilworth Lane, Springfield, Virginia, 22151 USA

Telephone +1 7036429090 (Eastern Time) · Fax +1 7036429094

imaging.org

Copyright (C) 2014, Society of Photo-Optical Instrumentation Engineers and The Society for Imaging Science and Technology.

Copying of material in this book for internal or personal use, or for the internal or personal use of specific clients, beyond the fair use provisions granted by the U.S. Copyright Law is authorized by the publishers subject to payment of copying fees. The Transactional Reporting Service base fee for this volume is $\$ 18.00$ per article (or portion thereof), which should be paid directly to the Copyright Clearance Center (CCC), 222 Rosewood Drive, Danvers, MA 01923. Payment may also be made electronically through CCC Online at copyright.com. Other copying for republication, resale, advertising or promotion, or any form of systematic or multiple reproduction of any material in this book is prohibited except with permission in writing from the publisher. The CCC fee code is $0277-786 \mathrm{X} / 14 / \$ 18.00$.

Printed in the United States of America.

Paper Numbering: Proceedings of SPIE follow an e-First publication model, with papers published first online and then in print and on CD-ROM. Papers are published as they are submitted and meet publication criteria. A unique, consistent, permanent citation identifier (CID) number is assigned to each article at the time of the first publication. Utilization of CIDs allows articles to be fully citable as soon as they are published online, and connects the same identifier to all online, print, and electronic versions of the publication. SPIE uses a six-digit CID article numbering system in which:

- The first four digits correspond to the SPIE volume number.

- The last two digits indicate publication order within the volume using a Base 36 numbering system employing both numerals and letters. These two-number sets start with 00, 01, 02, 03 , $04,05,06,07,08,09,0 \mathrm{~A}, 0 \mathrm{~B} \ldots \mathrm{OZ}$, followed by 10-1Z, 20-2Z, etc.

The CID number appears on each page of the manuscript. The complete citation is used on the first page, and an abbreviated version on subsequent pages. Numbers in the index correspond to the last two digits of the six-digit CID number. 


\section{Contents}

vii Conference Committee

\section{SESSION 1 ONLINE PHOTO AND IMAGING SERVICES}

902702 Representing videos in tangible products (Invited Paper) [9027-1]

R. Fageth, R. Weiting, CEWE Stiftung \& Co. KGaA (Germany)

902703 Aesthetic quality inference for online fashion shopping [9027-2]

M. Chen, J. Allebach, Purdue Univ. (United States)

902705 Full-color visibility model using CSF which varies spatially with local luminance [9027-4]

A. Reed, Digimarc Corp. (United States); D. Berfanger, Hewlett-Packard Co. (United

States); Y. Bai, K. Falkenstern, Digimarc Corp. (United States)

\section{SESSION 2 TEXT RECOGNITION IN MOBILE APPLICATIONS}

902706 Text recognition and correction for automated data collection by mobile devices [9027-5]

S. Ozarslan, P. E. Eren, Middle East Technical Univ. (Turkey)

902707 Text vectorization based on character recognition and character stroke modeling [9027-6]

Z. Fan, Xerox Corp (United States); B. Zhou, Peking Univ. (China); F. Tse, Xerox Corp. (United States); Y. Mu, T. He, Peking Univ. (China)

902708 Visual improvement for bad handwriting based on Monte-Carlo method [9027-7]

C. Shi, Peking Univ. (China) and Qingdao Univ. of Science and Technology (China);

J. Xiao, Peking Univ. (China); C. Xu, Peking Univ. (China), Qingdao Univ. of Science and

Technology (China), and State Key Lab. of Digital Publishing Technology (China);

W. Jia, Peking Univ. (China)

902709 Image processing for drawing recognition [9027-8]

R. Feyzkhanov, I. Zhelavskaya, Skolkovo Institute of Science and Technology (Russian Federation)

\section{SESSION 3 WEB AND SOCIAL MEDIA}

9027 OA A web-based video annotation system for crowdsourcing surveillance videos [9027-9] N. J. Gadgil, K. Tahboub, Purdue Univ. (United States); D. Kirsh, Univ. of California, San Diego (United States); E. J. Delp, Purdue Univ. (United States)

9027 OB A Markov chain model for image ranking system in social networks [9027-10]

T. T. Zin, Univ. of Miyazaki (Japan); P. Tin, T. Toriu, H. Hama, Osaka City Univ. (Japan) 
9027 OC Video quality assessment for web content mirroring [9027-11]

Y. He, Purdue Univ. (United States); K. Fei, G. A. Fernandez, Google Inc. (United States);

E. J. Delp, Purdue Univ. (United States)

SESSION 4 IMAGE, VIDEO, AND MULTIMEDIA ANALYTICS I

9027 OD Evolving background recovery in lecture videos [9027-13]

C. Genetet, G. Agam, Illinois Institute of Technology (United States)

9027 OE An HEVC compressed domain content-based video signature for copy detection and video retrieval [9027-14]

K. Tahboub, N. J. Gadgil, M. L. Comer, E. J. Delp, Purdue Univ. (United States)

SESSION 5 IMAGE, VIDEO, AND MULTIMEDIA ANALYTICS II

9027 OF Technology survey on video face tracking (Invited Paper) [9027-17]

T. Zhang, Hewlett-Packard Labs. (United States); H. Gomes, UFCG (Brazil)

9027 OG Textural discrimination in unconstrained environment [9027-18]

F. A. Albalooshi, V. K. Asari, Univ. of Dayton (United States)

$9027 \mathrm{OH} \quad$ Image denoising with multiple layer block matching and 3D filtering [9027-19]

Z. Fan, Xerox Corp. (United States)

9027 Ol Compact binary hashing for music retrieval [9027-21]

J. S. Seo, Gangneung-Wonju National Univ. (Korea, Republic of)

\section{SESSION 6 FACE/HUMAN BODY RECOGNITION AND DETECTION}

9027 OJ Efficient eye detection using HOG-PCA descriptor [9027-22]

A. Savakis, R. Sharma, Rochester Institute of Technology (United States); M. Kumar, FiveFocal (United States)

$9027 \mathrm{OL}$ Adaptive weighted local textural features for illumination, expression, and occlusion invariant face recognition [9027-24]

C. Cui, V. K. Asari, Univ. of Dayton (United States)

9027 OM Research on the face pattern space division in images based on their different views [9027-25]

Z. He, X. Ding, C. Fang, Y. Wang, Tsinghua Univ. (China)

INTERACTIVE PAPER SESSION

9027 ON Agglomerative clustering using hybrid features for image categorization [9027-15]

K. Damico, R. L. Canosa, Rochester Institute of Technology (United States)

iv 
902700 A comparison of histogram distance metrics for content-based image retrieval [9027-16] Q. Zhang, R. L. Canosa, Rochester Institute of Technology (United States)

9027 OP Video salient event classification using audio features [9027-20]

S. Corchs, G. Ciocca, M. Fiori, F. Gasparini, Univ. degli Studi di Milano-Bicocca (Italy)

Author Index 
SPIE-IS\&T/ Vol. 9027 902701-6

Downloaded From: https://www.spiedigitallibrary.org/conference-proceedings-of-spie on 26 Apr 2023 Terms of Use: https://www.spiedigitallibrary.org/terms-of-use 


\section{Conference Committee}

Symposium Chair

Sergio R. Goma, Qualcomm Inc. (United States)

Symposium Cochair

Sheila S. Hemami, Northeastern University (United States)

Conference Chairs

Qian Lin, Hewlett-Packard Laboratories (United States)

Jan P. Allebach, Purdue University (United States)

Zhigang Fan, Consultant (United States)

Conference Program Committee

Patricia Albanese, Rochester Institute of Technology (United States)

Vijayan K. Asari, University of Dayton (United States)

Susanne C. Boll, Carl von Ossietzky Universität Oldenburg (Germany)

Reiner Fageth, CeWe Color AG \& Company OHG (Germany)

Yuli Gao, Google (United States)

Michael J. Gormish, Ricoh Innovations, Inc. (United States)

Meichun Hsu, Hewlett-Packard Laboratories (United States)

Andrew A. Hunter, Hewlett-Packard Laboratories (United Kingdom)

Xiaofan Lin, A9.com, Inc. (United States)

Jerry Liu, Hewlett-Packard Laboratories (United States)

Yonghong Tian, Peking University (China)

Shengjin Wang, Tsinghua University (China)

Wiley H. Wang, Shutterfly (United States)

Rong Yan, Facebook Inc. (United States)

Yonghui Zhao, Apple Inc. (United States)

Session Chairs

1 Online Photo and Imaging Services

Qian Lin, Hewlett-Packard Laboratories (United States)

2 Text Recognition in Mobile Applications

Wiley H. Wang, Shutterfly (United States)

3 Web and Social Media

Reiner Fageth, CeWe Color AG \& Company OHG (Germany) 
4 Image, Video, and Multimedia Analytics I

Zhigang Fan, Consultant (United States)

5 Image, Video, and Multimedia Analytics II

Michael J. Gormish, Ricoh Innovations, Inc. (United States)

6 Face/Human Body Recognition and Detection

Jan P. Allebach, Purdue University (United States) 